\title{
COURT-PACKING AND THE CHILD LABOR AMENDMENT
}

\author{
Gerard N. Magliocca*
}

No amendment which any powerful economic interests or the leaders of any powerful political party have had reason to oppose has ever been ratified within anything like a reasonable time. And thirteen states which contain only five percent of the voting population can block ratification even though the thirtyfive States with ninety-five percent of the population are in favor of it. ${ }^{1}$

Franklin D. Roosevelt

We cannot take a stand consistently against the pending proposal to pack the United States Supreme Court and at the same time against the orderly amendment to the Federal Constitution that is proposed by this amendment. ${ }^{2}$

\section{Abbot Moffett, New York Assemblyman}

On March 9, 1937, President Franklin D. Roosevelt delivered a much-anticipated radio address to the nation defending his proposal to "reorganize" the Supreme Court. ${ }^{3}$ In that speech, FDR argued that the repeated invalidation of New

* Professor of Law, Indiana University-Indianapolis. Many thanks to Dan Cole, Heidi Kitrosser, Mike Pitts, Richard Primus, the staff at the Franklin D. Roosevelt Library in Hyde Park, NY, and the faculty at DePaul Law School for their assistance and comments on prior versions of this Article.

1. Franklin D. Roosevelt, $A$ 'Fireside Chat' Discussing the Plan for Reorganization of the Judiciary, in 6 THE PUBLIC PAPERS AND ADDRESSES OF FRANKLIN D. RoOSEVELT 122, 131 (Samuel I. Rosenman ed., 1941) [hereinafter Fireside Chat].

2. W.A. Warn, Child Labor Bill Dies in Assembly; Vote Is 102 to 42, N.Y. TIMES, Mar. 10, 1937, at 20 (describing the debate on the Child Labor Amendment to the Federal Constitution by the New York Assembly).

3. For more on this Fireside Chat, see 2 Bruce ACKerman, We The PeOPle: Transformations 326-27 (1998); JosePh Alsop \& Turner CATledge, The 168 DAYS 112-13 (1938); BurT SOlOMON, FDR v. THE CONSTITUTION: THE COURTPACKING Fight AND THE TRIUMPH OF DEMOCRACY 136-38 (2009); Turner Catledge, Roosevelt Asks that Nation Trust Him in Court Move; Resents 'Packing' Charges, N.Y. TIMES, Mar. 10, 1937, at 1 . The audio of the President's address can be found at http://www.presidency.ucsb.edu/mediaplay.php?id=15381\&admin $=32$. 
Deal statutes by the Justices meant that "we must take action to save the Constitution from the Court and the Court from itself." According to the President, this crisis could not be resolved by a new constitutional amendment, in part because of the "long course of ratification by three-fourths of all the States" required by Article Five. ${ }^{5}$ The only solution was to "infuse new blood" into the Court by adding many new Justices right away. ${ }^{6}$

Just a few hours before FDR went on the airwaves, the New York State Assembly rejected the Federal Child Labor Amendment (CLA), which was passed by Congress in 1924 but languished in the States during the 1920s and 1930s. ${ }^{7}$ By 1937, however, half the States had ratified the CLA and its supporters were optimistic about getting more to do so because they had

4. Fireside Chat, supra note 1, at 126; see Morehead v. New York ex rel. Tipaldo, 298 U.S. 587, 609-10 (1936) (holding that the New York minimum wage law violated due process); United States v. Butler, 297 U.S. 1, 68-72 (1936) (striking down the Agricultural Adjustment Act for exceeding Congress's authority under the Commerce Clause); Railroad Retirement Bd. v. Alton R. Co., 295 U.S. 330, 367-68 (1935) (striking down the Railroad Retirement Act for going beyond Congress's power under the Commerce Clause); Fireside Chat, supra note 1, at 125-26 (criticizing these decisions); see generally JefF Shesol, Supreme Power: Franklin RoOsevelt vs. The Supreme COURT (2010) (providing an excellent account of what led to the Court-packing crisis).

5. Fireside Chat, supra note 1, at 131; see U.S. CONST. art. V (setting forth the requirement that an amendment must be ratified by three-fourths of the States). FDR also said that agreeing on the text of an amendment and garnering the two-thirds vote necessary in each House of Congress would be too difficult. See id.

6. The President's proposal would have created an extra seat on the Court for every Justice over the age of seventy, and there were six Justices above that age at the time. See Barry Friedman, The Will of the People: How Public Opinion Has INFLUENCED THE SUPREME COURT AND SHAPED THE MEANING OF THE CONSTITUTION 3 (2009); William E. LeUCHTENBURG, THE Supreme COURT REBORN: The Constitutional ReVolution In the Age of Roosevelt 134 (1995).

7. See Warn, supra note 2, at 1 (discussing the vote); see also DAVID E. KYVIG, EXPLICIT AND AUTHENTIC ACTS: AMENDING THE U.S. CONSTITUTION 1776-1995, at 258-61 (1996) (describing the CLA's failure to get traction); WALTER I. TRATTNER, Crusade For the ChILdRen: A History of the National Child Labor COMMITTEE AND CHILD LABOR REFORM IN AMERICA 169-99 (1970) (discussing the ratification fight from 1924 through the mid-1930s); Julie Novkov, Historicizing the Figure of the Child in Legal Discourse: The Battle Over the Regulation of Child Labor, 44 AM. J. LEGAL HIST. 369, 394-403 (2000) (providing more background); Richard B. Sherman, The Rejection of the Child Labor Amendment, 45 MID-AMERICA 3 (1963) ("The collapse of the ratification drive revealed a far deeper distrust of the federal government and its efficacy as an instrument of reform than supporters of the amendment had anticipated.").

The CLA would have empowered Congress to limit, regulate, or prohibit the labor of people under eighteen. See Coleman v. Miller, 307 U.S. 433, 436 n.1 (1939) ("Section 1. The Congress shall have power to limit, regulate, and prohibit the labor of persons under eighteen years of age. Sec. 2. The power of the several States is unimpaired by this article except that the operation of State laws shall be suspended to the extent necessary to give effect to legislation enacted by the Congress."). The Fair Labor Standards Act accomplished the same goal in 1938. See Sherman, supra, at 14; see also United States v. Darby, 312 U.S. 100, 115 (1941) (upholding the FLSA). 
the backing of a powerful patron-the President. ${ }^{8}$ Two months prior to the New York vote, FDR wrote a letter to the governors of the states that had not ratified the CLA and urged them to make that one of their top priorities. ${ }^{9} \mathrm{He}$ also waded into the New York debate by sending public telegrams on behalf of the Amendment, though his lobbying was obviously unsuccessful. ${ }^{10}$ Thus, on March 10, readers of The New York Times were greeted by a front-page with two banner headlines-one about FDR's appeal for Court-packing and the other on the failure of the CLA in New York. ${ }^{11}$

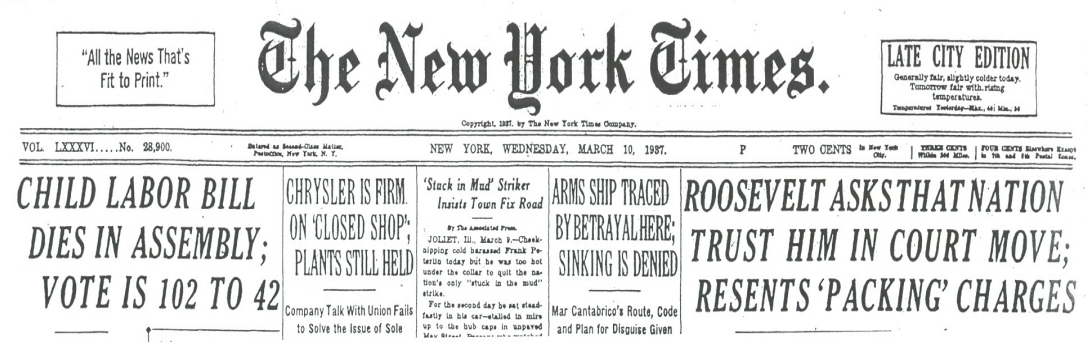

This Article explores the connection between the Child Labor Amendment and FDR's Court-packing plan. Conventional wisdom says that the long fight to ratify the CLA soured the President on the Article Five process and persuaded him that challenging the Justices was the better option. ${ }^{12}$ The truth is more complex. At the same time that the Administration was arguing that the deadlock over the CLA demonstrated that textual amendments were not a realistic way to achieve legal change, FDR was putting on a full-court press for the ratification

8. For a complete history of the CLA ratification struggle, see Coleman, 307 U.S. at $473 \mathrm{n}$.* (Butler, J., dissenting) (providing a chronology of state legislative action on the Amendment).

9. Roosevelt Pleads on Child Labor Act, N.Y. TIMES, Jan. 9, 1937, at 5; see also Memorandum from Francis Perkins, Sec'y of Labor, to FDR (Dec. 28, 1936), at 1 (on file with the FDR Presidential Library) (proposing that this letter be sent) [hereinafter Perkins Memo].

10. Roosevelt Spurs Child Labor Foes, N.Y. TIMES, Feb. 5, 1937, at 12 (providing the text of the telegram).

11. There is no evidence that the timing of these events was anything other than a coincidence, though it does nicely encapsulate the broader point of this Article. The Times headline is confusing in that it refers to the "Child Labor Bill" instead of the "Child Labor Amendment." There is no doubt, though, about what that story was talking about.

12. See, e.g., LeUChtENBURG, supra note 6, at 110 ("The President was especially influenced by the tiresomely long, unsuccessful saga of attempting to win ratification for the child-labor amendment, a struggle then in its thirteenth year."). 
of that amendment. ${ }^{13}$ More perplexing still, the President made it clear in his private letters during these weeks that he had no faith in the ratification process. ${ }^{14}$ This raises an obvious question - why did FDR put his authority behind the CLA?

While there is no smoking gun that describes the President's motives, the best explanation is that he supported the CLA because he thought that it would fail and that highlighting that failure would help the Court-packing plan. FDR's foes in Congress saw through this double-game and tried to expose his real motives by backing a revised version of the CLA that would have required state ratification conventions to vote on the proposal within ninety days: an idea that would have undercut the rationale for Court-packing. ${ }^{15}$ All of these maneuvers came to an abrupt and inconclusive end, however, when the Justices executed their "switch-in-time" a month after the President's address. ${ }^{16}$ Thus, the Child Labor Amendment ratification debate, which reached its climax at about the same time that the Courtpacking plan was proposed and the Justices flipped, sheds new light on that crucial series of events.

The most important takeaway from my story is that the view that state ratification is a high hurdle for constitutional amendments is an interpretation of Article Five that only emerged in 1937. When Congress passed the CLA in 1924, the prevailing consensus was that state legislatures were nothing but

13. For a sample of the Administration's views on why the CLA's failure supported Court-packing, see President Roosevelt's Plan for the Reorganization of the Federal Judiciary: Hearing Before the S. Judiciary Comm., 75th Cong. 14 (1937) (statement of Attorney General Cummings) (on file with the FDR Presidential Library) ("The phraseology of any proposed amendment would be the subject of endless debate and, once submitted, might suffer the fate of the child labor amendment which has been pending for thirteen years."). The hearings on FDR's Supreme Court proposal began one day after the events described at the start of the text.

14. See infra text accompanying notes $105-109$.

15. See Mr. Vandenberg's Amendment, N.Y. TIMES, Mar. 30, 1937, at 22 (describing his proposal to reintroduce the CLA with modified language and require that it be voted on by state ratification conventions within ninety days) [hereinafter Vandenberg]; id. ("If Mr. VANDENBERG is correct in believing that Congress, in submitting an amendment to State conventions, has the right to set the time for the calling of such conventionsand many constitutional authorities believe that it has - then he is justified in declaring that his amendment could be 'ratified within ninety days' if the full power of the Administration were put behind it.").

16. See NLRB v. Jones \& Laughlin Steel Corp., 301 U.S. 1, $48-49$ (1937) (upholding the Wagner Act); West Coast Hotel Co. v. Parrish, 300 U.S. 379, 399-400 (1937) (upholding a Washington state minimum wage statute and overruling Adkins v. Children's Hospital); ALSOP \& CATLEDGE, supra note 3, at 144-47 (recounting the switch-in-time); SOLOMON, supra note 3, at 156-61, 179-82 (same). 
a rubber stamp for amendments. ${ }^{17}$ By 1937, however, state legislatures were viewed as a major obstacle. In part, this was because of the difficulties that the CLA encountered in the States. In part, though, this transformation was the product of FDR's deliberate effort to convince people, contrary to the historical record, that state ratification of amendments was hard. His argument on this point became an axiom in constitutional practice even though his attempt to pack the Court failed.

Accordingly, we need to reconsider what the constitutional crisis of 1937 was all about. When lawyers and historians reflect on the Court-packing plan, they usually reach two conclusions. First, the failure of FDR's proposal fixed the number of justices at nine for all time. ${ }^{18}$ Second, the Court learned that it could not stand in the way of determined public opinion and must not stray too far from the majority's constitutional views. ${ }^{19}$ The CLA debate adds a third leg to this stool. In the first three months of 1937, political elites and ordinary citizens were persuaded that state legislatures could not be relied upon to ratify major constitutional amendments. This presumption, which was reinforced by the defeat of the Equal Rights Amendment (ERA) during the 1970s, is now so strong that the difficulty of moving an Article Five amendment through the States is treated as a fact. ${ }^{20}$

Part One explores how the Article Five process was viewed when the CLA was proposed and shows that most people

17. See 65 CONG. REC. 10,088 (1924) (statement of Sen. Reed) ("We know from experience that State legislatures have rarely in recent years ever paused even to debate a proposed constitutional amendment .... I do not mean to say that rule is universal, but I do affirm it to be general."); infra text accompanying notes 47-56 (discussing the effort by CLA opponents to thwart the proposal by requiring that ratification be by conventions rather than by legislatures)

18. See, e.g., Stephen B. Burbank, The Architecture of Judicial Independence, $72 \mathrm{~S}$. CAL. L. REV. 315, 322 (1999) ("The number nine is fixed in our brains not so much as a function of current legal awareness but as a number that has assumed the proportion of a constitutional understanding. This understanding emerged from a time of crisis, the crisis that President Roosevelt's court-packing plan precipitated in 1937.”).

19. See FRIEDMAN, supra note 6, at 4 ("In effect, a tacit deal was reached: the American people would grant the justices their power, so long as the Supreme Court's interpretation of the Constitution did not stray too far from what a majority of the people believed it should be. For the most part, this deal has stuck.").

20. Of course, one could say that neither the CLA nor the ERA failed in the sense that their substance was eventually incorporated into statutory and case law, see David A. Strauss, The Irrelevance of Constitutional Amendments, 114 HARV. L. REV. 1457, 1475-78 (2001) (making this point), but with respect to the ERA that is a debatable point. For a recent discussion about the relevance of the CLA's failure for the debate over originalism, see John O. McGinnis \& Michael B. Rappaport, Originalism and the Good Constitution, 98 GEO L.J. 1693, 1724-26 (2010). 
thought that ratification by state legislatures was easy. Part Two examines why the CLA ran into a wall of opposition that undermined this assumption about the role of state legislatures. Part Three looks at how the close attention given to the CLA in the first three months of 1937 influenced the debate on Courtpacking and transformed the meaning of Article Five.

\section{THE GOLDEN AGE OF TEXTUAL AMENDMENTS}

This Part traces how the States treated proposed constitutional amendments until the passage of the CLA in 1924. The evidence is clear that state legislatures almost always ratified an amendment sent by Congress and did so quickly. After all, four were approved in the decade prior to the proposal on child labor. ${ }^{21}$ Indeed, the notion that state legislatures were an insignificant barrier within Article Five was so widely accepted that congressional enemies of the CLA made their stand by proposing that state conventions rather than legislatures be required to ratify the Amendment. ${ }^{22}$

\section{A. From the BiLl of Rights to Women's SufFrAGE}

A review of the historical record reveals that getting state legislatures to endorse a textual amendment was not a problem prior to 1924. In the midst of the Court-packing fight, a young Republican congressman with a bright future, Everett Dirksen, assembled data on this question to refute the President's claim that the states could not ratify amendments within a reasonable time..$^{23}$ Dirksen's research showed that only one of the first

21. See, e.g., AKHIL REed AMAR, AMERICA's CONSTITUTION: A BIOGRAPHY 40528 (2005) (describing the constitutional amendments on the income tax, the direct election of Senators, prohibition, and women's suffrage).

22. See 65 CONG. REC. 7286 (1924) (stating the suggested change in the House of Representatives as: "This article shall be inoperative unless it shall have been ratified as an amendment to the Constitution by the conventions of the several States, as provided in the Constitution, within seven years from the date of the submission hereof by Congress"); id. at 10009 (making a similar proposal in the Senate that lacked the sevenyear time limit); $c f$. KYVIG, supra note 7, at 250 ("In the 1920s expressions of concern about Article $\mathrm{V}$ tended to come not from those who feared that amendment was too difficult but from those who worried that it was too easy.").

23. See Time Factor in Amendments, N.Y. TIMES, Feb. 21, 1937, at 54 [hereinafter Time Factor]. The first ten amendments (as a group) took 810 days to receive approval by three-fourths of the States, the Eleventh Amendment took 339 days, the Twelfth Amendment 229 days, the Thirteen 309 days, the Fourteenth 756 days, the Fifteenth 356 days, the Sixteenth 1,278 days, the Seventeenth 359 days, the Eighteenth 396 days, the Nineteenth 444 days, the Twentieth 327 days, and the Twenty-First 286 days. Id. While there might be some minor errors in these figures, they are substantially correct and confirm the broad point about the speed of state ratification. 
twenty-one amendments, the Sixteenth, took longer than three years to ratify. ${ }^{24}$ The Supreme Court made a similar point in Coleman v. Miller ${ }^{25}$ which addressed the question of whether the ratification process for the CLA was justiciable, when it said that "one year, six months and thirteen days was the average time used in passing upon amendments which have been ratified since the first ten amendments ... three years, six months and twentyfive days has been the longest time used in ratifying." 26

Not only were constitutional amendments prior to the 1920s adopted rapidly, but there were only four passed by Congress that were not ratified. Two were in the original proposal for the Bill of Rights. One involved limits on congressional pay raises and was eventually ratified - two hundred years later-as the Twenty-Seventh Amendment. ${ }^{27}$ The other sought to regulate the size of the House of Representatives and the number of constituents that a member could represent. ${ }^{28}$ This proposal came up one state shy of the total needed for ratification. ${ }^{29}$ Next came the Anti-Title Amendment, which was passed by Congress in 1810 and would have revoked the citizenship of anyone who accepted a title from a foreign power or, without the consent of Congress, a foreign gift. ${ }^{30}$ That also fell one state short. ${ }^{31}$ Finally,

24. Id. While the CLA was pending, the Twentieth and Twenty-First Amendments were ratified in less than a year. Id. The Twenty-First, though, was ratified by conventions. See infra text accompanying notes 88-91 (examining the logic behind this exception)

25. 307 U.S. 433 (1939).

26. Id. at 453; see also Dillon v. Gloss, 256 U.S. 368, 372 (1921) (stating that prior to the Eighteenth Amendment "seventeen of these [amendments] had been ratified by the Legislatures of three-fourths of the states - some within a single year after their proposal and all within four years"); ACKERMAN, supra note 3, at 261-65 (discussing Coleman).

27. See U.S. CONST. amend. XXVII ("No law, varying the compensation for the services of the Senators and Representatives, shall take effect, until an election of Representatives shall have intervened."); Michael Stokes Paulsen, A General Theory of Article V: The Constitutional Lessons of the Twenty-Seventh Amendment, 103 YALE L.J. 677, 678-81 (1993) (discussing that long-delayed ratification).

28. See 1 Stat. 97 (1789) ("After the first enumeration required by the first article of the Constitution, there shall be one Representative for every thirty thousand, until the number shall amount to one hundred, after which the proportion shall be so regulated by Congress, that there shall not be less than one hundred Representatives, nor less than one Representative for every forty thousand persons, until the number of Representatives shall amount to two hundred; after which the proportion shall be so regulated by Congress, that there shall not be less than two hundred Representatives, nor more than one Representative for every fifty thousand persons."); AMAR, supra note 21, at 82 (discussing this proposal and noting that its goals were accomplished through legislation).

29. See AMAR, supra note 21 , at 82 .

30. See Res. 2, 11th Cong., 2d Sess., 2 Stat. 613 (1810) ("If any citizen of the United States shall accept, claim, receive or retain any title of nobility or honour, or shall, without the consent of Congress, accept and retain any present, pension, office or 
there was the Corwin Amendment, which was passed by a lameduck Congress in 1861 as a last ditch effort to prevent secession by providing permanent protection to slavery. ${ }^{32}$ With the onset of the Civil War, that proposal never got off the ground. ${ }^{33}$ These scattered instances of state legislative resistance to textual amendments-all of which occurred long before the 1920s-do not weaken the claim that state ratification was considered easy before the passage of the CLA.

In any event, this remote history was far less relevant for the Congress that proposed the CLA than the recent ratification of the Sixteenth, Seventeenth, Eighteenth, and Nineteenth Amendments in quick succession. Senator Henry Cabot Lodge, for example, told his colleagues that although he would vote for the CLA he was "not at all in favor of the practice we have fallen into of constantly amending the Constitution." ${ }^{34}$ A House member echoed this sentiment and said that amendments were now "being proposed and falling as thick as 'the autumn leaves which strew the vales in Vallombrosa." ${ }^{35}$ In this context, an argument that state legislatures constituted a bottleneck for Article Five would have been met with incredulity.

\section{B. CHILD LABOR AND THE CONVENTION POISON PILL}

The Child Labor Amendment was proposed because of the Supreme Court's refusal to sanction ordinary legislative measures taken to abolish the practice. ${ }^{36}$ In 1916, Congress passed the Owen-Keating Act, which barred the interstate shipment of goods made by children under the age of fourteen

emolument of any kind whatever, from any emperor, king, prince or foreign power, such person shall cease to be a citizen of the United States, and shall be incapable of holding any office of trust or profit under them, or either of them.").

31. See KYVIG, supra note 7, at 117.

32. See J. Res. 13, 36th Cong., 2d Sess., 12 Stat. 251 (1861) ("No amendment shall be made to the Constitution which will authorize or give to Congress the power to abolish or interfere, within any State, with the domestic institutions thereof, including that of persons held to labor or service by the laws of said State.").

33. See KYVIG, supra note 7, at 151 (noting that only three states ratified the Corwin Amendment); see also AMAR, supra note 21, at $457 \mathrm{n}^{*}$ (pointing out that Illinois ratified the amendment in an "irregular" manner).

34. 65 CONG. REC. 10,124 (1924) (statement of Sen. Lodge).

35. Id. at 7287 (statement of Rep. Garrett).

36. See Bailey v. Drexel Furniture Co. (Child Labor Tax Case), 259 U.S. 20, 36, 44 (1922) (striking down a federal excise tax on the profits earned through child labor as violating the Tenth Amendment); Hammer v. Dagenhart, 247 U.S. 251, $276-77$ (1918) (voiding a federal statute that barred the shipment in interstate commerce of goods made by child labor as exceeding Congress's commerce clause power), overruled by United States v. Darby, 312 U.S. 100, 116-17 (1941). 
and those between fourteen and sixteen who worked more than eight hours a day or forty hours per week. ${ }^{37}$ A constitutional challenge reached the Court two years later in Hammer $v$. Dagenhart, ${ }^{38}$ where five Justices held that the Act was beyond Congress's Commerce Clause authority because the goods themselves were harmless and the "production of articles, intended for interstate commerce, is a matter of local regulation." ${ }^{39}$ The Court also held that " $[\mathrm{t}]$ here is no power vested in Congress to require the states to exercise their police power so as to prevent possible unfair competition" stemming from unequal labor laws. ${ }^{40}$ Justice Holmes dissented and argued that when states "seek to send their products across the State line they are no longer within their rights." ${ }^{41}$ Besides, "if there is any matter upon which civilized countries have agreed-far more unanimously than they have with regard to intoxicants and some other matters over which this country is now emotionally aroused - it is the evil of premature and excessive child labor." ${ }^{42}$

Congress responded with the Child Labor Tax Law, which imposed a ten-percent excise tax on the profits earned on the same categories of goods that had been prohibited by the OwenKeating Act. ${ }^{43}$ The Court rejected this measure also, with Chief Justice Taft reasoning that the "analogy to the Dagenhart Case is clear" and that "[t]o give such magic to the word 'tax' would be to break down all constitutional limitation of the powers of Congress and completely wipe out the sovereignty of the states." As a result, the only course open to critics of child labor was an Article Five amendment. It soon became clear that there was broad support for an amendment, just as there had been for the legislation attacking child labor. ${ }^{45}$ Even Calvin Coolidge, hardly a progressive, endorsed the CLA. ${ }^{46}$

37. See Hammer, 247 U.S. at 268 n.1 (quoting the Act); TRATTNER, supra note 7, at 127-31 (describing the debate on the Act); Novkov, supra note 7, at 373 (summarizing the legislation).

38. 247 U.S. 251 (1918).

39. Id. at 272 .

40. Id. at 273

41. Id. at 281 (Holmes, J., dissenting).

42. Id. at 280 (Holmes, J., dissenting).

43. See Bailey, 259 U.S. at 34-35 (providing the text of the statute); TrATTNER, supra note 7, at 139-40 (describing the tax); Novkov, supra note 7, at 373 (same).

44. Bailey, 259 U.S. at $39,38$.

45. See TRATTNER, supra note 7, at 128 (stating that the Owen-Keating Act passed the House of Representatives by 343 to 46); id. at 131 (listing the Senate tally as 52 to 12); id. at 140 (stating the Senate vote on the child labor tax was 50 to 12 and the House vote was 310 to 11). For more on the backdrop of the CLA in Congress, see Sherman, supra note 7 , at $4-7$. 
Outnumbered foes of the Amendment tried to kill the proposal by introducing a requirement that ratification in the States be done by conventions and not by legislatures. ${ }^{47}$ The thrust of their argument was that legislatures did not provide any meaningful input into the deliberative process. ${ }^{48}$ As one Congressman explained:

It is known to every student of American affairs that the consideration of constitutional amendments by the several legislatures has been in some if not many States almost perfunctory. There has been little or no discussion of the amendments by the several legislatures. There has been no argument against argument, no judgment against judgment, no real contest, and no real debate exciting interest or contributing information. ${ }^{49}$

Likewise, the Senator who introduced a convention substitute there said the "facts show that the people elected to

I do not have a good explanation for why the CLA moved so easily through Congress but ran into a buzz saw in the States. One possibility is that opponents of the amendment did not get organized until the proposal reached the States. Congress could also have been out of synch with the sentiments of the country on this issue, though I am not sure why that would have been the case.

46. See Calvin Coolidge, Annual Message (Dec. 6, 1923), in 21 A Compilation of the Messages AND PaPers OF THE PREsidents 1789-1925, at 9350 (James D. Richardson ed., 1925) ("For purposes of national uniformity we ought to provide, by constitutional amendment and appropriate legislation, for a limitation of child labor.").

47. See U.S. CONST. art. V (stating that constitutional amendments may be ratified by state conventions or legislatures). There were substantive points made against the CLA, but those are considered in Part II. See infra text accompanying notes 63-86.

48. Another concern was that voters ought to have a more direct say in the ratification process. See 65 CONG. REC. 7287 (1924) (statement of Rep. Garrett) ("[A]s conditions of law stand today, less than 3,000 individuals in the United States can amend the organic law of the United States without there being in any way the slightest opportunity for the masses of the people themselves to pass upon ... such an amendment.") Some of this feeling stemmed from the ratification of the Eighteenth Amendment in Ohio, where a referendum rejected Prohibition and, under state constitutional law, nullified the legislative action. See KYVIG, supra note 7, at 242-43 (describing this development). The Supreme Court held that this procedure was inconsistent with Article Five. See Hawke v. Smith, 253 U.S. 221, 227 (1920) (stating that the method of ratification was expressly limited and "admits of no doubt in its interpretation. It is not the function of courts or legislative bodies, national or state, to alter the method which the Constitution has fixed."). This decision left the impression (at least for some people) that the ratification process was undemocratic. See KYVIG, supra note 7, at 246 (quoting H.L. Mencken's view that "free people, asked to give up their ancient liberties, ought to have a fair chance to say yes or no, and not be rooked of them by a process suggesting that whereby a three-card monte man operates upon the husbandmen at a county fair").

49. 65 Cong. ReC. 7286 (1924) (statement of Rep. Montague); see id. at 10,074 (statement of Sen. Overman) ("Suppose this amendment shall be submitted now, will the people have any voice in its ratification? No. It will be railroaded through the legislatures which will meet next January ....”). 
the legislatures do not reflect the calm, considered judgment of the people of the States." ${ }^{50}$ Another Senator held that a "member of a State legislature justifies himself in that attitude by saying that both branches of Congress have already approved the measure, and that he yields to their superior wisdom and judgment, and, therefore, he does not pause to investigate."

Supporters of the CLA dismissed these objections as a transparent attempt to impede ratification. ${ }^{52}$ One Representative said that every "gentleman in this House, whether he is for or against this amendment, understands that the motive ... at least the result to be accomplished by the adoption of the proposed amendment - would be to defeat any child labor law. ${ }^{, 33}$ Others could not understand how legislative ratification, which had been used for every constitutional amendment up to that time, could be problematic. ${ }^{54}$ When the votes were cast, the convention alternative failed overwhelmingly. ${ }^{55}$ Both Houses

50. Id. at 10,009 (statement of Sen. Bayard). Some Senators also argued that many of the recent amendments were passed in haste and would not have been ratified if conventions were used. See id. at 10,074 (statement of Sen. Overman) ("I am pledged never again to vote for a constitutional amendment unless it shall be submitted to the people for their ratification. We all know the history of the adoption of the fourteenth, fifteenth, sixteenth, seventeenth, and eighteenth amendments. We know that in their ratification the people were not consulted; we know that that the voice of the people could not be heard . . .."); id. at 10,009 (statement of Sen. Bayard) ("Had any one of these matters, from the thirteenth, fourteenth, and fifteenth amendment up, been sent to the several States for ratification by conventions, I question if the thirteenth, fourteenth, or fifteenth amendments would have been ratified. ... I question very much whether the eighteenth and nineteenth would ....").

51. Id. at 10,088 (statement of Sen. Reed).

52. Cf. KYVIG, supra note 7, at 267 ("More than a touch of irony could be found in evolving attitudes about constitutional amendment during the 1920s. Conservatives came to argue that an amendment's validation required direct popular participation in its approval. Meanwhile, progressive reformers, usually the advocates of participatory democracy, grew leery of its application to the amendment process.").

53. 65 CONG. REC. at 7286 (statement of Rep. Foster); see id. ("That must be the purpose and desire of any person, in my judgment, advocating the adoption of this amendment. Otherwise, why should we abandon the ratification by State legislatures and place it in the conventions?"); see also id. at 10,109 (statement of Sen. Walsh) (stating that the convention substitute was designed "to put another obstacle in the way of this reform which the Congress of the United States has twice indorsed and the House of Representatives has now three times indorsed, each time by an overwhelming vote").

54. See id. at 10,010 (statement of Sen. Robinson) ("[I]f the convention plan is such a good one and so thoroughly calculated, as the Senator states, to reflect the popular will, and the legislature plan is such a bad one and so calculated to reflect the contrary of the popular will, why the people have never insisted upon having ratifications through conventions but have always acquiesced in ratifications through State legislatures.").

55. See id. at 10,141 (stating that the vote was 22 to 58 in the Senate); id. at 7289 (stating that the vote was 84 to 175 in the House). 
then passed the CLA by more than the two-thirds necessary under Article Five. ${ }^{56}$

The reason that this procedural debate is so fascinating is that less than fifteen years later the opposite argument was made. State legislatures became the bogeyman of constitutional reform and those trying to block the President's Court-packing plan maintained that conventions were the best way to expedite ratification. ${ }^{57}$ The CLA's rough ride through the States partly explains that turnaround.

\section{THE RATIFICATION DEBATE IN THE STATES}

This Part examines the arguments made against the CLA that stymied its ratification from 1924 until $1937 .{ }^{58}$ Critics of the proposed Amendment were particularly concerned about its effect on parochial schools, the threat posed to parental rights by subjecting childhood to federal authority, and the fear that expressly authorizing Congress to regulate labor would be the first step toward communism. ${ }^{59}$ While these charges stopped the CLA in its tracks, they did not change the view that legislatures were the best way of ratifying amendments.

\section{A. Substantive ATtACKS AND HyPERbOLE}

Though Arkansas ratified the CLA a few weeks after the congressional vote, only five more states did so over the next six years. ${ }^{60}$ Even worse for anti-child labor activists was that more than twenty legislatures rejected the proposal in the 1920s, which

56. See id. at 10,142 (listing the final tally as 61 to 23 ); id. at 7295 (listing the vote as 297 to 69 in the House).

57. See infra text accompanying notes $133-141$.

58. I will not dwell on the arguments in favor of banning child labor, as they are not that hard to understand today. See 65 CoNG. REC. 7168 (1924) (statement of Rep. Nelson) ("The Constitution of America is the world's greatest charter of human emancipation. It was written by American men to protect man's right to life, liberty, and happiness; it is now also the instrument for the enfranchisement of American women; and it shall be the refuge of freedom for American children from every form of child slavery forever."); KYVIG, supra note 7, at 165 (quoting Herbert Hoover's endorsement of the CLA because child labor was "a blight ... more deplorable than war").

59. $C f$. Robert H. JACKSON, THE StRUgGLE FOR Judicial Supremacy 261 (1941) ("In the effort to use language broad enough so that judicial construction could not again mutilate it, a sweeping authority to the Federal Government was proposed. Its breadth aroused the apprehensions of many people, some of whom had no sympathy with the Court's disposition of the Child Labor cases. But because of these apprehensions it made slow progress towards ratification.").

60. See KYVIG, supra note 7, at 261 (explaining that three states ratified the CLA between 1925 and 1930); Sherman, supra note 7, at 14 (noting that only Arkansas, Arizona, and California had ratified the CLA in January 1925). 
meant that more than the one-quarter total that could veto an Article Five amendment was on record as saying no. ${ }^{61}$ This lopsided result was the product of a strange coalition that included the Catholic Church, white southerners, the textile industry, and farmers, who probably agreed on nothing other than their animus toward the CLA. ${ }^{62}$

One leader of the campaign against ratification, especially in Massachusetts and New York, was the Catholic Church, which feared that the Amendment would let Congress regulate parochial schools. ${ }^{63}$ Catholics argued that education was implicated by the proposal since federal authority over "labor" could be read to cover the mental labor of students in the classroom. ${ }^{64}$ This was not an idle threat, as Oregon had passed an initiative in 1922 banning parochial schools. ${ }^{65}$ The Court invalidated this law in Pierce v. Society of the Sisters of the Holy

61. See KYVIG, supra note 7, at 260 (stating that "one or both houses of twenty-one state legislatures had rejected the amendment"). Kansas rejected the CLA in 1925, and that Legislature's attempt to overturn this result in 1937 was the main issue in Coleman. See Coleman v. Miller, 307 U.S. 433, 435-36 (1939); see id. at 447-50 (concluding that Congress could recognize a state ratification even though there had been a prior rejection).

62. See Reva B. Siegel, She The People: The Nineteenth Amendment, Sex Equality, Federalism, and the Family, 115 HARV. L. REV. 947, 1010 (2002) (explaining that the CLA "fell victim in the ratification phase to a conservative network including the Sentinels of the Republic, the Woman Patriots, the National Association of Manufacturers, the American Farm Bureau Federation, and a small number of prominent religious leaders").

63. Barbara Bennett Woodhouse, "Who Owns The Child?": Meyer and Pierce and the Child as Property, 33 WM. \& MARY L. REV. 995, 1062 (1992) ("Mainstream Catholics viewed the Amendment with alarm, believing it posed a danger to parochial education and transferred to the state powers that ought to belong to parents."); see also TRATTNER, supra note 7, at 176 ("[T] Massachusetts was a telling blow."); $i d$. (describing Catholic criticism of the CLA in Massachusetts and New York due to the threat "to the Church's prerogatives, especially in the field of education.").

64. See Letter from Charles F. Hurley, Gov. of Massachusetts, to FDR (Feb. 3, 1937), at 2 (on file with the FDR Presidential Library) ("Education might conceivably fall within the scope of their authority, since "Labor" means any mental or physical exertion.") [hereinafter Hurley Letter]; Warn on Child Labor Ban, N.Y. TIMES, Feb. 8, 1937, at 5 (discussing the "[f]ear that adoption of the Federal Child Labor Amendment might lead to abolition of Roman Catholic parochial schools"); see also TRATTNER, supra note 7, at 171-72 (stating that "Roman Catholics and some Lutherans" worried about the CLA "since the dictionary definition of labor was 'physical or mental toll") $c f$. KYVIG, supra note 7, at 259 (quoting the resolution of the Georgia Legislature, which rejected the CLA saying that it would give Congress "all state authority over education").

65. See Pierce v. Soc'y of the Sisters of the Holy Names of Jesus \& Mary, 268 U.S. 510, 530-32 (1925) (describing the law and the constitutional challenge by a Catholic school); Woodhouse, supra note 63, at 1017 (noting that the Ku Klux Klan was instrumental in the passage of the Oregon plan). 
Names of Jesus and Mary, ${ }^{66}$ but that case was still pending when many states (including Massachusetts) considered the CLA. ${ }^{67}$ Even after Pierce was decided, the proposal still disturbed Catholics because it could be construed as allowing Congress to enact the same kind of sweeping prohibition. ${ }^{68}$

A related line of attack, which came mostly from conservative groups such as the Sentinels of the Republic, was that the CLA was a dangerous invasion of parental authority. ${ }^{69}$ One state representative said that in recent years "[t]hey have taken our women away from us by constitutional amendment, they have taken our liquor away from us; and now they want to take our children." ${ }^{70}$ In part, this argument stemmed from the assumption that the wages of child workers (and therefore the decision about whether they should work) belonged to their parents. $^{71}$ The more emotional appeals against the CLA raised

66. 268 U.S. 510 (1925); id. at 534 (holding that "the right to conduct schools was property and that parents and guardians, as a part of their liberty, might direct the education of children by selecting reputable teachers and places").

67. Massachusetts, for example, held a non-binding referendum on the CLA in November 1924 that resulted in a landslide against the proposal. See TRATTNER, supra note 7, at 176. Pierce was not decided until 1925.

68. CLA supporters responded that there were no cases equating labor with education, therefore the concern about school autonomy was unwarranted. See, e.g., Text of Gov. Lehman's Appeal for Child Labor Amendment, N.Y. TIMES, Mar. 6, 1937, at 4 ("For centuries we have had laws dealing with both subjects, yet nobody has mixed them up. Our law books are filled with decisions holding to the contrary and stating that labor means physical toll, not the process of acquiring an education.") [hereinafter Lehman Appeal].

69. See, e.g., 65 CONG. REC. 7174 (1924) (statement of Rep. Crisp) (“[T]his proposed amendment goes further, in my judgment, than any amendment that has ever been proposed to the Constitution so far as the control of human rights is concernedthe God-given, inalienable right of parents to regulate and control their own children whom God gave them."); id. at 10,097 (statement of Sen. Ransdell) ("Just as soon as the children are large enough to be of some assistance to their real parents they must be delivered to their statutory father in Washington."); KYVIG, supra note 7, at 258-59 (describing the Sentinels of the Republic as an organization that "looked back unhappily at every amendment from the Fourteenth onward"); Novkov, supra note 7, at 399-400 (quoting an anti-CLA radio address in Massachusetts that asked "Christian mothers" whether they could "afford to gamble with your children's happiness at stake? Can you afford to risk contamination of the Massachusetts home?"); Sherman, supra note 7, at 8 (stating that a common charge against the CLA was that "[p]arental control of children would be surrendered to the bureaucracy").

70. TRATTNER, supra note 7 , at 171 ; see Woodhouse, supra note 63 , at 1065 (quoting the Columbia University President's view that "[n]o American mother would favor the adoption of an amendment that would empower Congress to invade the rights of parents and to shape family life to its liking").

71. See, e.g., Woodhouse, supra note 63, at 1064 ("Children who received pay envelopes were expected to turn them over to the parent unopened."). As with parochial education, the issue of parental rights was a live one during the 1920s. See Meyer v. Nebraska, 262 U.S. 390, 399 (1923) (holding that the Due Process Clause protected the right to "establish a home and bring up children"). 
the specter of a federal ban on household chores or the involuntary removal of children from their parents. ${ }^{72}$ Accordingly, critics often referred to the proposal as the "Youth Control Amendment.",73

Another powerful theme of the opposition was that the CLA could be enforced only through very intrusive means, which fed on the growing unpopularity of Prohibition. ${ }^{74}$ One state representative captured this feeling by stating that congressional power over child labor would "undoubtedly necessitate the appointment of a horde of snooping, meddlesome and tax-consuming investigators and officials reminiscent of the odious activities of those employed to enforce the Federal prohibition laws." ${ }^{, 75}$ Most of the divisive civil liberties cases during the 1920s involved alcohol, and thus the argument that yet another amendment that expanded federal authority could lead to a diminution of privacy was reasonable. ${ }^{76}$ More

72. See KYVIG, supra note 7, at 259-60 (quoting a CLA supporter who said that voters "had been told the most amazing things and were afraid the government was going to step in and take their children from them, that children were to be prevented from working in the home or on the farm, that no child under eighteen was to be allowed to do any thing but school work, that parents were to be deprived of the authority over the children, and much more of the same kind"); Sherman, supra note 7, at 11-12 ("[C]harges were circulated that even household chores would be forbidden if the amendment were ratified."); $c f$. Hurley Letter, supra note 64, at 2 ("It is not too fantastic to visualize ... compulsory military training, involuntary work on public projects, forced attendance in concentration camps.").

73. See Brief of Petitioners at 31, Coleman v. Miller, 307 U.S. 433 (1939) (No. 7) (quoting an ABA Journal article that referred to the CLA as the "Child Control Amendment"); see also Lehman Appeal, supra note 68, at 4 ("It is also claimed that the amendment seriously interferes with the home and with parental authority.... They call it a 'Youth Control Amendment."').

74. See, e.g., KYVIG, supra note 7, at 261 ("No doubt resistance to further amendment was linked to the unhappiness with national prohibition that continued to grow throughout the 1920s."); TRATTNER, supra note 7, at 170 (stating that an argument against the CLA was that it "would mean an ominous increase of federal power, and an extensive bureaucracy would arise to enforce the laws that would be enacted").

75. Hurley Letter, supra note 64, at 3; see also 65 CONG. REC. 7195 (1924) (statement of Rep. Hawes) ("[I]t will build up a great national bureau, with thousands of police, called inspectors, who will intrude themselves into the homes, the schools, and the private affairs of the citizens of our States."); Warn, supra note 2, at 20 ("'Governor Lehman has said that Congress is composed of reasonable men. But what about the Eighteenth Amendment and the Volsted Act?"' (quoting Charles McConnell, New York Assemblyman)); cf. TRATTNER, supra note 7, at 171 ("The prohibition (and, to some extent, the woman suffrage) amendment altered the views of many regarding sumptuary legislation and left widespread antagonism toward reformers and constitutional change.").

76. See Olmstead v. United States, 277 U.S. 438, 466 (1928) (upholding the use of wiretaps to enforce Prohibition against a Fourth Amendment challenge), overruled by Katz v. United States, 389 U.S. 347 (1967); KYVIG, supra note 7, at 276-77 (discussing some examples); see generally Robert Post, Federalism, Positive Law, and the Emergence of the American Administrative State: Prohibition in the Taft Court Era, 48 WM. \& MARY 
broadly, this unease about Prohibition energized those who argued against the CLA on traditional federalism grounds. ${ }^{77}$

Moving from the plane of principle to politics, the business and agricultural interests that benefited from child labor were also active in fighting the $\mathrm{CLA}^{78}$ For instance, the textile industry took a strong stand against anything that would deprive them of the dainty hands that worked the power looms. ${ }^{79}$ Newspaper publishers were critical of the proposal because paperboys were a key link in the distribution chain. ${ }^{80}$ Farmers' organizations fought the CLA because youth were essential for the operation of family farms. ${ }^{81}$ And the Manufacturer's Record, a leading commercial trade journal, contended that the CLA "would be the greatest thing ever done in America in behalf of the activities of Hell. It would make millions of young people ... idlers in brain and body, and thus make them the devil's best workshop." ${ }^{82}$ Of course, the CLA did not require the abolition of

L. REV. 1 (2006) (exploring this issue in depth).

77. The states'-rights criticism was weak given that the CLA said that state regulation of child labor was not preempted. See Coleman v. Miller, 307 U.S. 433, 435 n.1 (1939) (quoting $\S 2$ of the CLA, which stated "[t]he power of the several States is unimpaired by this article except that the operation of State laws shall be suspended to the extent necessary to give effect to legislation enacted by the Congress"). But the issue was still raised. See KYVIG, supra note 7, at 309 (stating that the American Bar Association "decried the amendment as an unwarranted federal invasion of the rights of states and families"); Novkov, supra note 7, at 400 (stating that the best argument against the CLA was that the "amendment would allow for improper federal control over the authority of the states").

78. See, e.g., 65 CONG. REC. 7278 (1924) (statement of Rep. Perlman) ("Who are opposed to this amendment? In the main those who wish to exploit children for their own profit."); TRATTNER, supra note 7, at 173 ("The National Association of Manufacturers made defeat of the amendment its major item of business for 1924."); Novkov, supra note 7, at 402 ("[T] he image of the American icon of the yeoman farmer subjected to federal control was meant to frighten potential amendment supporters.").

79. See KYVIG, supra note 7, at 258 (explaining that textile manufacturers mounted the successful court challenges in Dagenhart and Bailey and played an important role in opposing the CLA); TRATTNER, supra note 7, at 174 (noting that one of the leading agrarian lobbies against the CLA was "actually headed by the cashier of a cotton mill bank in North Carolina; [and] its vice-president was an employee of a cotton mill store").

80. See KYVIG, supra note 7, at 258 ("Newspaper publishers, employers of young boys for sales and delivery, joined in the attack.").

81. See Sherman, supra note 7 , at 11 ("[A]grarian hostility to the child labor amendment was substantial. A large proportion of the working children ages ten to fifteen were engaged in agricultural pursuits. Although statutory regulation of such labor was not then proposed by supporters of the amendment, many farmers were certainly apprehensive that such interference would be forthcoming." (footnote omitted)) Browning Opposes the Law, N.Y. TIMES, Jan. 9, 1937, at 5 (quoting the Tennessee Governor, who opposed the CLA because he was "not ready to turn over to a Washington bureau the discrimination as to whether a farmer can have his boy help him make a crop").

82. TRATTNER, supra note 7, at 173 . 
any form of child labor - the text only authorized Congress to do so-but that point was often lost in the heat of the debate. ${ }^{83}$

Finally, there was the claim that the CLA was just part of a communist plot to destroy America. ${ }^{84}$ The official publication of the Boston archdiocese argued during the debate in Massachusetts that the Amendment was "more in keeping with Soviet Russia than with the fundamental principles of the American Government." ${ }^{85}$ In New York, a state representative stated that "I do not accuse all of those who favor this amendment of being Communists or Socialists merely because all Communists and Socialists favor it, but I do claim that far beyond the innocent and plausible purpose of many sincere people there is definitely sinister purpose...." outrageous charges probably got a sympathetic hearing because of the recent establishment of the Soviet Union and the fear created by the Russian Revolution.

83. See Coleman v. Miller, 307 U.S. 433, 435 n.1 (1939) ("The Congress shall have power to limit, regulate, and prohibit the labor of persons under eighteen years of age."); cf. TRATTNER, supra note 7, at 169 (quoting The New Republic's view that "[t]he friends of the amendment were totally unprepared to combat the flood of distorted propaganda which let loose upon them. They had been accustomed to argue [sic] their case before reasonable and attentive human beings. They suddenly found themselves compelled to discuss a matter of public policy with a monstrous jazz band").

84. See, e.g., 65 CONG. REC. 9963 (1924) (quoting the petition of the Woman Patriot Publishing Co., which asserted that the CLA "is a straight Socialist measure. It is also promoted under direct orders from Moscow"); Novkov, supra note 7, at 399 ("[Critics] appealed to fears of communism and socialism by portraying the amendment as merely a first step in a sinister plan to establish complete state control ...."); Sherman, supra note 7 , at 9 ("[R]ed-scare tactics were widely used to condemn the child labor amendment as un-American, and there is no doubt that this approach was an important factor in its defeat.").

85. Sherman, supra note 7, at 13; see 65 CONG. REC. 10,088 (1924) (statement of Sen. Reed) ("People are advocating this measure who have advocated everything socialistic and destructive; people are advocating this measure who have been going to school literally to those doctrinaires of Russia, who think that the child is the ward of the state; that it should be taken from its mother's arms and put under the tutelage and supervision of state officials.").

86. Warn, supra note 2, at 20 (quoting Laurens M. Hamilton); see also TRATTNER, supra note 7, at 172 ("Opponents of child labor reform deliberately aroused these feelings, stigmatizing the amendment as a subversive movement spawned by the Russian Revolution, thus adding another dimension to the arguments against it."); Warn, supra note 2, at 20 ("'Those who favor the present amendment will not realize that in seeking to free children from one form of slavery they may well be delivering those same children and generations yet unborn to the same kind of controlled, regimented legal slavery that children in other parts of the world are subjected to." (quoting Laurens M. Hamilton, New York State Assemblyman). 


\section{B. THE TwENTIETH AND TwENTY-FIRST AMENDMENTS}

Notwithstanding the inability of state legislatures to ratify the CLA, when Congress proposed two new constitutional amendments in the early 1930s there was no sign that the debate had changed any minds about Article Five. The Twentieth Amendment, which revised the start of the presidential and congressional terms and presidential selection procedures under unusual conditions, was sent to the States in the traditional way in 1932 and ratified in less than a year. ${ }^{87}$ The Twenty-First Amendment was passed in 1933 with a requirement that state conventions ratify the repeal of Prohibition, but that was a special exception unconnected to the CLA. ${ }^{88}$

Anti-Prohibitionists argued that the convention route was necessary because too many state legislatures were skewed in favor of the "dry" faction and would not vote for repeal. The Wickersham Commission, which conducted a thorough review of Prohibition for President Hoover, concluded that the ratification of the Eighteenth Amendment was the result of malapportioned legislatures that over-represented rural voters who were more likely to support a ban on alcohol. ${ }^{89}$ Oddly enough, this confirmed the argument made by the critics of the CLA who claimed that state legislatures did not provide an adequate check on Article Five. ${ }^{90}$ Three of the commissioners took the position that Congress should submit any repeal of Prohibition for ratification by state conventions to bypass the opposition in the

87. See U.S. CONST. amend XX; KYVIG, supra note 7, at 274 (observing that the Twentieth Amendment was passed by Congress in March 1932 and ratified in January 1933). This Amendment made four changes. First, the presidential and vice-presidential inauguration was moved to January 20th. See id. at $\S 1$. Second, the start of the congressional session was moved up to January 3rd. See id. at $\S 2$. Third, new procedures were established for what would happen if the President-elect died or was deemed ineligible prior to the inauguration. See id. § 3. Finally, procedures were established for what would happen if a candidate for President or Vice-President died in an election where no candidate received a majority of the electoral vote. See id. at $\S 4$. For a discussion of these provisions, see AMAR, supra note 21, at 428-30.

88. See U.S. CONST. amend. XXI, § 1 ("The eighteenth article of amendment to the Constitution of the United States is hereby repealed."); id. at $\S 3$ (requiring ratification by state conventions).

89. See KYVIG, supra note 7, at 277-78 (describing the Wickersham Report); see also AMAR, supra note 21, at 416 ("State and congressional apportionment rules in the 1910s had tended to favor rural and heavily native-born regions.); $c f$. Baker v. Carr, 369 U.S. 186, 237 (1962) (holding that equal protection challenge to malapportioned state legislatures did not constitute a nonjusticiable political question).

90. See supra text accompanying notes $47-51$. There is no indication that state legislative districting skewed the outcome with respect to the CLA or any other constitutional amendment. 
state legislatures. ${ }^{91}$ The Democratic National Convention adopted this proposal as a platform plank in 1932, and Congress acted upon that recommendation a year later. ${ }^{92}$

While the Twenty-First Amendment was seen as a significant precedent during the Court-packing debate, the convention method was used in 1933 because Prohibition was considered a unique case where the procedural choice made a substantive difference. ${ }^{93}$ There is no indication in the legislative history or in any other sources that the obstacles encountered by the CLA were a factor in that decision. And the ratification of the Twentieth Amendment confirms that there was no general change in attitude about the role of state legislatures even though the CLA had been pending for nine years at that point. It would take the guile and rhetoric of one of our greatest presidents to alter the understanding of Article Five.

\section{THE MISSING STORY OF THE 1937 CRISIS}

This Part discusses the previously unknown link between the CLA and the Court-packing plan from December 1936 until March 29, 1937, when the country learned of Justice Owen Roberts' switch-in-time in West Coast Hotel Co. v. Parrish. ${ }^{94}$ With the onset of the Great Depression, support for prohibiting child labor increased as a way to increase wages, and half of the States had ratified the Amendment by the beginning of $1937 .^{95}$ At that point, the President gave the CLA a strong endorsement. But appearances were deceiving. The inability of the States to ratify the Amendment, which FDR emphasized through his high-profile support, turned into one of his leading arguments for Court-packing. In the process, the CLA's rough ride through

91. See KYVIG, supra note 7 , at 278 ; see also AMAR, supra note 21 , at 416 ("[M]alapportionment lived on in many states, prompting Anti-Prohibitionists to sidestep state legislatures altogether in the ratification process.").

92. See KYVIG, supra note 7, at 280-86 (summarizing the debate and the rapid ratification of the Twenty-First Amendment by the state conventions).

93. See infra text accompanying notes 131-139.

94. 300 U.S. 379, 399-400 (1937) (upholding the Washington minimum wage statute and overruling Adkins v. Children's Hospital); Alsop \& CATLEDGE, supra note 3, at 144 (stating that this case "was the great moment"); SOLOMON, supra note 3, at 159-62 (discussing contemporary reactions to Justice Roberts' about-face).

95. Luther A. Huston, Child Labor Amendment Hope Gains, N.Y. TIMES, Jan. 17, 1937, at 65 (noting that Kentucky ratified the CLA earlier in the week, making it the twenty-fifth state to do so); see also Novkov, supra note 7, at 395 ("A second and larger wave of ratifications began in 1933 and ran through 1937, reflecting a new concern with child labor borne of the Depression."). 
state legislatures became the operative precedent under Article Five.

\section{A. PRobing FDR's ConstituTional Motives}

Let us begin by examining how the President got behind the CLA and why his action should be viewed with some skepticism. Following FDR's overwhelming reelection, the Secretary of Labor, Francis Perkins, sent him a memo contending that " $[t]$ he immediate outlook for ratification of the child labor amendment is encouraging but definite impetus by you is necessary to turn the scale. A letter from you to the incoming Governors of the States that have not ratified, which will have regular sessions in 1937 would be immensely valuable." ${ }^{, 6}$ FDR agreed and wrote that letter to great fanfare on January 8, 1937:

I am sure you will agree with me that one of the most encouraging developments of the past few years is the general agreement that has been reached that child labor should be permanently abolished.

$\ldots$

However, it is clearly indicated that child labor, especially in low-paid, unstandardized types of work, is increasing. I am convinced that nation-wide minimum standards are necessary and that a way should be found promptly to crystallize in legal safeguards public opinion in behalf of the elimination of child labor.

Do you not agree with me that ratification of the child-labor amendment by the remaining twelve States whose action is necessary to place it in the Constitution is the obvious way to early achievement of our objective? I hope that you will agree that this can be made one of the major items in the legislative program of your State this year. ${ }^{97}$

The White House was definitely interested in this issue, as I found a handwritten note of unknown authorship in FDR's files

96. Perkins Memo, supra note 9, at 1; see Letter from Frances Perkins, Sec. of Labor, to Marvin H. McIntyre, Ass't Sec'y to the President (Dec. 26, 1936) (on file with the FDR Presidential Library) ("I talked with the President after Cabinet meeting about sending this letter to the Governors of the 19 States which have not yet ratified the Child Labor Amendment. He said that he would like to do it, and asked me to prepare what I thought would be a suitable letter.").

97. Roosevelt Pleads on Child Labor Act, N.Y. TiMES, Jan. 9, 1937, at 5; see id. ("Many observers believe that the President's plea will achieve the object, despite the stormy debates that have been waged on the subject of child labor."). 
listing all of the governors who received the letter and noting their replies. ${ }^{98}$

All of this looks straightforward enough, but the timing of FDR's intervention is curious because prior to 1937 he did not lift a finger to help the CLA. At a 1935 press conference, the President made his indifference clear:

Q: It seems there is anti-child labor organization complaining that you are exerting influence with state legislatures to have that amendment ratified?

THE PRESIDENT: Not exerting influence. I made my position very clear a year ago and I have stuck to that.

Q:And that is?

THE PRESIDENT: No change. I am in favor of it but I am exerting no influence.

His hands-off approach is partly explained by the National Industrial Recovery Act of 1933, which essentially suspended antitrust law and promoted cooperative practices within industries. ${ }^{100}$ These codes made great strides in reducing child

98. See FDR Official File 58-A ("Letters Sent to Governors and Gov. Elect of following states-re Child Labor Amendment") (on file with the FDR Presidential Library); Press Conference No. 339, in 9 COMPLETE PRESIDENTIAL PRESS CONFERENCES OF FRANKLIN D. RoOSEVElT 108 (Da Capo Press 1972) (1937) ("Q: Have you heard from the nineteen Governors who wrote in regard to the child labor amendment? THE PRESIDENT: I think we have replies from every one of them and from the smaller states the information I get is that it looks pretty favorable.").

99. Press Conference No. 182, in 5 COMPLETE Presidential Press Conferences of Franklin D. RoOsEvelt 102-03 (Da Capo Press 1972) (1935). My search through the presidential archives in Hyde Park confirms that FDR was doing nothing to aid the CLA before 1937. He received many requests from CLA supporters for the kind of strong endorsement that he provided in 1937, see Letter of Courtney Dinwiddie, General Sec'y of the National Child Labor Committee, to FDR (Oct. 3, 1934) (on file with the FDR Presidential Library) ("Strong backing of the Amendment by the Administration, as the method for perpetuating the child labor gains, would, we are confident, insure success. If you agree, may we hope for your active support of the Amendment?"), but these requests were ignored or met with tepid statements. And when Francis Perkins drafted congratulatory telegrams for FDR to send to Indiana and Idaho upon their ratification of the CLA in 1935, the President told his aide to "forget about these." See Memorandum of Francis Perkins, Sec'y of Labor, to Marvin McIntyre (Feb. 9, 1935) (on file with the FDR Presidential Library) (including her draft telegrams with a negative cover note attributed to FDR).

100. See FRIEDMAN, supra note 6, at 200 ("The NIRA attempted to deal with the problem of economic collapse by permitting businesses in different economic sectors to enter into cooperative codes of fair competition, which also were to include provisions for collective bargaining for wages and hours."); TRATTNER, supra note 7, at 190 ("Passed in June 1933 ... the NIRA sought to end cutthroat competition by promoting cooperative action among trade groups, to raise prices by limiting production, and to guarantee labor a reasonable work week and decent wages."). 
labor and led the President to say in the 1934 State of the Union that the practice was "abolished." 101 Nevertheless, when the Court struck down the Act in A.L.A. Schechter Poultry Corp. v. United States, ${ }^{102}$ FDR did not change his posture on the CLA. ${ }^{103}$ The shift to a pro-amendment stance came only in 1937, which begs the question - why then?

Furthermore, the President's open support of the CLA is hard to reconcile with his private correspondence during the same period, which shows nothing but disdain for the Article Five process. ${ }^{104}$ For instance, just six weeks after his endorsement of the Amendment, he told a friend that no "controversial amendment, especially one which in effect is opposed by a political party, has ever been passed within a short space of time." 105 FDR told Felix Frankfurter (then a member of the Harvard faculty) at about the same time that if he was "without a conscience, I would gladly undertake for a drawing account of fifteen or twenty million dollars (easy enough to raise) to guarantee that an amendment would not be ratified .... In other words, I think I could prevent ratification in thirteen states." 106 Finally, he confided to his White House Press Secretary that ratification of any amendment was unlikely since it was easy "for moneyed interests to buy up enough legislatures to prevent action." $" 107$

The most revealing comment came in a letter to Charles C. Burlingham in which FDR explained why he was pursuing

101. TRATTNER, supra note 7, at 196; see id. at 190-95 (discussing the impact of these codes on child labor); Letter from FDR to Courtenay Dinwiddie, National Child Labor Committee (Nov. 8, 1934) (on file with FDR Presidential Library) ("One of the accomplishments under the National Recovery Act which has given me the greatest gratification is the outlawing of child labor.").

102. 295 U.S. 495 (1935).

103. See KYVIG, supra note 7, at 308 (explaining that Schechter "rendered child labor restrictions, along with the other features of the codes, unenforceable"); TRATTNER, supra note 7, at 200 (stating that "the child employment curve shot upward again" after Schechter)

104. The President's public comments were also inconsistent with his stated position on the CLA, as just one day before his letter he told Congress in his State of the Union that "there is little fault to be found with the Constitution of the United States as it stands today. The vital need is not an alteration of our fundamental law, but an increasingly enlightened view with reference to it." KYVIG, supra note 7, at 302.

105. Letter from FDR to Arthur F. Mullen (Feb. 25, 1937) (on file with the FDR Presidential Library).

106. KYVIG, supra note 7, at 303 (quoting a letter from FDR to Frankfurter dated February 9, 1937).

107. LEUCHTENBURG, supra note 6, at 111 (quoting a diary entry recording a conversation between Press Secretary Early and Raymond Clopper); see also id. at 282 n.100 (stating that this entry was dated February 8, 1937). 
Court-packing instead of a constitutional amendment to secure the New Deal. He told Burlingham that "[i]f you were not as scrupulous and ethical as you happen to be, you could make five million dollars as easy as rolling off a log by undertaking a campaign to prevent the ratification by one house of the Legislature, or even the summoning of a constitutional convention in thirteen states for the next four years. Easy money." 108 This was illuminating because Burlingham was the head of the Nonpartisan Committee for Ratification of the Federal Child Labor Amendment! ${ }^{109}$ In effect, FDR was saying that the whole project was a waste of time. If the President believed that and felt free to express that view in private to one of the CLA's chief supporters, then why did he back the Amendment in public?

One explanation for the strange timing and for the inconsistency behind FDR's support of the CLA is that in January 1937 he was secretly preparing the Court-packing plan. ${ }^{110}$ Attorney General Homer Cummings was the only Cabinet member aware of the President's scheme, and the proposal was put together with the help of only a few Justice Department attorneys until its release on February 5th. ${ }^{111} \mathrm{~A}$ connection between the Court-packing plan and the President's intensified support of the CLA is suggested by the fact, discussed in the next section, that the Administration used the failure of the state ratification process as a significant argument for judicial reform. ${ }^{112}$ Ironically, Herbert Hoover was the first person to see this link when he joined FDR's call for the ratification of the CLA because it was "important that we have orderly

108. Letter from FDR to Charles C. Burlingham (Feb. 23, 1937) (on file with the FDR Presidential Library), at 1.

109. Dr. Butler Fights Child Labor Law, N.Y. Times, Jan. 18, 1937, at 2.

110. For some background on the President's thinking about Court-packing, see Alsop \& CATLEDGE, supra note 3, at 22-37 (discussing his deliberations after the 1936 presidential election); LEUCHTENBURG, supra note 6, at 82-131 (reaching back even further into FDR's first term).

111. Alsop \& CATLEDGE, supra note 3, at 43 ("At the White House the President nursed his delightful secret, while Homer Cummings and the serious, hard-working Solicitor General, Stanley Reed, labored over their papers and law books at the Justice Department. Only one man was allowed to help them-Cummings' personal assistant, Alexander Holtzoff . . ..."); SOLOMON, supra note 3, at 93 ("Night after night during the following weeks, Homer Cummings used a secluded entrance into the White House to confer with the president and then slip away unseen."); see also FRIEDMAN, supra note 6, at 217 (stating that the plan was announced in a Cabinet meeting on February 5,1937).

112. See infra text accompanying notes $119-128$. 
constitutional change instead of pressure on the independence of the Supreme Court."113

The critical difference between Hoover and the White House must have rested with their respective assessments of the likelihood that the CLA would be ratified. After all, Hoover's view was right with the assumption that the proposal would be adopted by three-fourths of the States. The ratification of an Article Five amendment would undercut the argument that constitutional change could be achieved only by enlarging the Court. This makes FDR's support of the CLA even more inexplicable, especially since just one day before he introduced the Court-packing proposal he sent a public telegram urging the New York Legislature to ratify the CLA. ${ }^{114}$

The fog surrounding the President's actions disappears if we assume that he was sure the CLA would not be ratified. In that case, backing the Amendment would not harm the Court plan. Instead, it would reinforce the argument that Article Five was obsolete. There was a robust expectation in February, created partly by FDR's public appeal, that the CLA would be ratified. ${ }^{115}$ Indeed, the opinion polls (crude as they were at the time) demonstrated that the proposal was favored by seventy-six percent of voters and commanded a majority in every single state. ${ }^{116}$ Failure of the ratification process in light of this widespread support would make it clear that the constitutional will of the nation could not be expressed through standard means. This is what the President was counting on because he

113. Hoover Supports Roosevelt in an Appeal for Early Ratification of Child Labor Ban, N.Y. TIMES, Jan. 11, 1937, at 6; see supra text accompanying note 2 (making the same connection in the debate on the CLA in the New York Legislature).

114. See Roosevelt Spurs Child Labor Foes, N.Y. TIMES, Feb. 5, 1937, at 12 ("I want all friends and supporters of the Child Labor Amendment to the Constitution to know that my attitude toward this measure to protect the rights of childhood has not changed. Only last month I wrote a letter to the Governors of nineteen States asking that ratification of the amendment be made one of the major items in the legislative program in their States this year. I sincerely hope that my own State will be among those to ratify.").

115. See Huston, supra note 95, at 65 ("[S] upporters of the amendment and observers of the legislative trends feel that the assertion that 1937 may be the year in which the Twenty-second Amendment to the Constitution will join other historic changes in the basic law, is not without foundation."); see also Child Labor Ban Gains Momentum, N.Y. TIMES, Feb. 7, 1937, at 68 (stating that the CLA "is increasingly debated" and "seems destined at last for approval by the Legislature" in New York).

116. TRATTNER, supra note 7, at 201-02 (describing this poll); see also Letter from John Tibby, Associate Editor of the American Institute of Public Opinion to Stephen Early, Assistant Secretary to FDR (Jan. 12, 1937) (providing a poll that showed majority support for the CLA in forty-five of the forty-eight states). 
wanted the Court-packing plan to get through Congress. ${ }^{117}$ Though there is no direct evidence in FDR's papers that spells out his thinking on this point, no other explanation is convincing. ${ }^{118}$

The most plausible alternative theory is that the President's support of the CLA was an independent fallback position in case his effort to pack the Court failed, but this interpretation is not supported by the facts. First, FDR's lack of interest in the CLA prior to 1937 works against the view that it was not connected to his confrontation with the Justices. Second, he did not express support for any other proposed constitutional amendment in 1937. If pursuing reform through Article Five were a realistic option, one would think that the President would have at least taken an interest in some of the textual amendments that were being discussed in Congress. Third, the logical time for pushing the CLA as Plan B would have been after the defeat of the Court scheme, not while it was under consideration. The more closely one looks at the issue, the more clear it becomes that FDR was simply using the CLA as a stalking horse for Courtpacking.

\section{B. ARTICLE THREE or ARTICLE FiVE?}

Further proof for the hypothesis that the President used the CLA as a political lever can be found in his acts following the announcement of the Court-packing plan. The White House launched a coordinated campaign to sell the message that the CLA's failure in the state legislatures showed that Article Five could not be relied upon to overcome the Supreme Court's resistance to the New Deal. ${ }^{119}$ At the same time, however, FDR

117. Since Francis Perkins was unaware of the Court-packing plan when she wrote her memo to FDR, see supra text accompanying note 96, her support for the CLA must be taken as genuine.

118. See infra text accompanying note 135 (describing Republican claims that FDR was not truly interested in the ratification of the CLA).

119. See Map a Farm Drive to Push Court Bill, N.Y. TIMES, Feb. 28, 1937, at 35 (quoting Senator Pope of Idaho, who said that "Is it not certain that most of those who are bitterly opposed to the President's proposal would also be opposed to any amendment to enlarge the powers of Congress to enact social legislation? The same influences that have so long delayed the ratification of the Child Labor Amendment will be active in delaying, if not defeating, any other such constitutional amendment."); Time Factor, supra note 23, at 54 ("[T]hose favoring court reform by statute are prepared to cite the thirteen-year retardation of the proposed Child Labor Amendment as an example of the time involved in driving an amendment through three-fourths of the forty-eight States. They are ready to say that the course of this proposed addition to the charter proves conclusively what can be done when power is applied to opposition."). 
continued to express his support for the Amendment. ${ }^{120}$ What is often overlooked is that while the country was debating the Court's future in February and March 1937, the CLA was under active consideration in the States, and there was a feedback loop between the two issues that operated in the President's favor until Congress launched a surprise initiative at the end of March. ${ }^{121}$

For example, the leading spokesman for the Administration's plan was Attorney General Cummings, and on February 15 he gave a national radio address that explained why the CLA experience was an argument in favor of Court-packing:

Those who are violently opposing the President's recommendations insist the reforms he seeks to bring about should be accomplished by amending the Constitution and by that method alone. This is the strategy of delay and the last resort of those who desire to prevent the adoption of any Constitutional amendment. The child labor amendment, submitted thirteen years ago, has not yet been ratified. ${ }^{122}$

Just one week later, though, Cummings spoke on behalf of the CLA in hearings held by the New York Assembly:

The vital problem of child labor can best be solved by nationwide action. The amendment would clearly empower the Congress to deal with the matter. The suggestion advanced by certain opponents of the amendment that it may result in prohibiting children to help their parents at home or on the farm is not entitled to a moment's consideration. It is a mere device to distract attention from the merits of the amendment itself." $" 123$

120. See Telegram from Taylor E. Julien to FDR (Feb. 8, 1937) (on file with the FDR Presidential Library) (asking the President whether the CLA should be supported vigorously with a cover note from FDR stating "Write him today and say 'Yes."); see also Memorandum from F.H. LaGuardia, Mayor of New York to FDR (Mar, 27, 1937) (reporting on the Maryland Legislature's consideration of the CLA at the request of the White House).

121. See Child Amendment Votes, N.Y. TIMEs, Feb. 12, 1937, at 3 (stating that New Mexico ratified the CLA but was rejected by South Dakota); see also Ratified by 28th State, N.Y. TiMES, Feb. 26, 1937, at 6 (noting the ratification by Kansas). For more on the national debate about Court-packing, see ACKERMAN, supra note 3, at 317-33; ALSOP \& CATLEDGE, supra note 3, at 63-134; LEUCHTENBURG, supra note 6, at 132-42. The New York Times headline of March 10,1937 was a rather vivid representation of this link. See supra text accompanying notes 11-12.

122. Address by Homer Cummings, Att'y Gen. of the United States (NBC, CBS, and Mutual Broadcasting radio broadcast Feb 15. 1937). The Attorney General said the same thing to the Senate Judiciary Committee. See supra note 13.

123. W.A. Warn, Roosevelt Makes Child Labor Plea to the Assembly, N.Y. TIMES, Feb. 23, 1937, at 1; see id. ("Advocates and opponents of ratification voiced their pleas 
The President added to these mixed signals by sending yet another telegram to New York on the same day urging ratification. $^{12}$

This brings us back to the Fireside Chat of March 9, in which he gave a detailed defense of the Court-packing plan and put a new spin on the state ratification process. ${ }^{25}$ In that speech, FDR said that "[n]o amendment which any powerful economic interests or the leaders of any powerful political party have had reason to oppose has ever been ratified within anything like a reasonable time" and he observed that thirteen states with just five percent of the population could veto any proposal. ${ }^{126}$ There is no doubt that this passage referred to the CLA, as no other amendment supported the President's claim. ${ }^{127}$ With this statement, he was pulling a bait-and-switch by asking voters to see a current event (the fight over the CLA) as emblematic of Article Five. That effort was made possible by FDR's cagey decision to make the public more aware of the CLA through his endorsement. What is remarkable is that the President's rhetoric was so powerful that modern lawyers simply accept without question that what he said is true.

The substance of the Fireside Chat and FDR's political sense was vindicated in the following three weeks as the CLA ran out of gas. Not only did New York reject the proposal shortly before the President's speech, but Connecticut, Massachusetts, and Nebraska also voted no in March. ${ }^{128}$ At that

for more than six hours in an atmosphere of high tension rarely paralleled at a legislative hearing. The Assembly chamber and galleries were filled. Not in a generation had a hearing on a legislative measure attracted so large a throng.").

124. Id. ("I am informed that the Child Labor Amendment will come up for discussion today at a public hearing before the Judiciary Committee of the Assembly. The bill having passed the Senate, I sincerely trust that the House will take similar favorable action as quickly as possible. I hope very much that my own home State will be prompt in ratification.").

125. See supra text accompanying notes 3-6.

126. Fireside Chat, supra note 1, at 131.

127. Time Factor, supra note 23 , at 54 ("Advocacy of an amendment is, the administration says through Mr. Cummings, the last resort of those objecting to anything new, and indeed is utterly impractical because of the tedious and uncertain ratification process. But this is met with statements that on the average only about fifteen and onethird months were necessary for the State sanction of the last eleven changes in the supreme law of the land. Seven of these eleven amendments were ratified by threefourths of the States in less than one year."); see also KYVIG, supra note 7, at 304 ("The president made no mention of recent episodes that suggested otherwise about the time needed to achieve an amendment. The lame duck and prohibition repeal amendments of 1933 did less to stir confidence than the thwarted child labor amendment did to provoke contrary expectations.").

128. See supra text accompanying notes 7-11; see also Connecticut Bars Child 
point, "[e]ven the most ardent backers of the proposal conceded that it was highly improbable that it would be written into the Constitution this year." ${ }^{129}$ Opponents of the Court-packing plan in Congress, however, were about to upset the President's calculations.

Three days after FDR's Fireside Chat, The New York Times ran an editorial entitled "Child Labor: What Now?" that described the state of play with respect to the CLA. ${ }^{130}$ After stating that "[n]othing can disguise the fact that the action of the New York Assembly is a serious setback for the child labor amendment," the Times contended that Congress should draft a new CLA and "follow the precedent of prohibition repeal, not to the Legislatures but to "conventions' of the States." ${ }^{131}$ Citing recent public opinion polls, the editorial stated that it was "extremely probable" that such a proposal would be ratified. ${ }^{132}$

On March 27, Senator Arthur Vandenberg, a Republican from Michigan, followed up on this suggestion and introduced a revised CLA with a convention requirement. ${ }^{133}$ The Senator stated that if the Administration got behind his idea the CLA could be ratified within ninety days. ${ }^{134}$ Savvy political strategists,

Amendment, N.Y. TIMES, Mar. 19, 1937, at 3 (discussing the CLA's defeat by the Connecticut state house); Child Labor Curb Doomed This Year, N.Y. TIMES, Mar. 21, 1937, at 13 ("The Child Labor Amendment to the Federal Constitution, approved by only four States in 1937, appeared today to have slight prospect of full ratification this year . . . ."); Ban on Child Labor Suffers New Blow, N.Y. TIMES, Mar. 27, 1937, at 4 (discussing the rejection of the CLA by the Nebraska Legislature) [hereinafter New Blow]; To End Child Labor, N.Y. TIMES, Mar. 26, 1937, at 20 (noting the no vote in Massachusetts) [hereinafter End Child Labor].

129. New Blow, supra note 128, at 4.

130. Child Labor: What Now?, N.Y. TIMES, Mar. 12, 1937, at 22 [hereinafter What Now?].

131. Id.; End Child Labor, supra note 128, at 20 ("The new amendment, following the precedent of prohibition repeal, should be submitted to 'conventions' and not to the Legislatures of the States. This is the way, and at present it is the only way, of submitting the proposal directly to the people; and there seems to be little doubt that they would overwhelmingly approve it.").

132. See What Now?, supra note 130, at 22 (stating that eighty-three percent of voters supported the CLA in New York despite its rejection by the Assembly); id. ("As the delegates to such conventions have no other function than to vote for or against the amendment, the popular vote electing delegates is virtually a direct referendum on the question.").

133. Vandenberg Gives a New Amendment to Ban Child Labor, N.Y. TiMES, Mar. 28, 1937, at 18 [hereinafter New Amendment]. His proposal also contained some revised text that allowed Congress to "limit and prohibit" child labor but not to "regulate" the practice, defined the object of the authority as "labor for hire" and not "labor," and lowered the age from eighteen to sixteen. See Vandenberg, supra note 15, at 22.

134. See Vandenberg, supra note 15, at 22; see also Louis Stark, New National Labor Laws Pondered, N.Y. TIMES, Apr. 4, 1937, at 70 ("A storm of opposition to the Vandenberg resolution is already brewing among the proponents of the pending 
however, understood that FDR would never embrace the Vandenberg Amendment because a real prospect of ratification would kill the Court plan:

Some Republican observers expressed the belief that it would not be considered good strategy by President Roosevelt and his advisers to push for immediate ratification of a child labor amendment because the failure of the necessary thirty-six States to ratify the pending amendment is one of the most telling arguments used by proponents of the President's court plan against counter-proposals to accomplish the end which he has in view by means of a constitutional amendment. ${ }^{13}$

While Vandenberg's intent is just as obscure as the President's, it is doubtful that he brought forward a new CLA just because he liked kids. After all, the Senator was a leading critic of Courtpacking and was busy organizing a bipartisan coalition to oppose the President. ${ }^{136}$ It would have been an amazing coincidence if the new amendment were proposed for reasons that were completely unconnected to the Court fight, just as it is hard to believe that FDR suddenly took an interest in the CLA in January without an ulterior motive. ${ }^{137}$

The Vandenberg Amendment contains several remarkable features that merit discussion. First, the new-and-improved CLA was a brilliant attempt to outflank the President. If he supported the proposal and it was ratified quickly, that would be devastating to his argument that Article Five was now an anachronism. If he opposed the idea, then that would open FDR

amendment; it is being held in check only by the preoccupation of Congress with the President's judiciary reform program. The Senator from Michigan, however, has promised to press his plan at the first opportunity. He says he is certain that his proposed amendment could be ratified by thirty-six States in ninety days.").

135. New Amendment, supra note 133, at 1 . Granted, there were others who took the President at his word that he wanted the CLA ratified. See Vandenberg, supra note 15, at 22 ("It has been suggested that the President might refuse to support a new amendment of this sort on the ground that the long delay in approval of the old child labor amendment has been the chief argument against referring the proposal to enlarge the court directly to the people in the form of a constitutional amendment. But it is inconceivable that the President, of all people, would do anything to prolong the exploitation of children for one day simply in the hope of scoring a political point.").

136. See LEUCHTENBURG, supra note 6, at 140 (describing Senator Vandenberg's planning on how to oppose the President); see also ACKERMAN, supra note 3, at 332 (stating that Vandenberg gave a national radio address on March 2 attacking the Courtpacking proposal).

137. The Senate Judiciary Committee approved the Vandenberg Amendment in June, New Child Labor Amendment Put to Senate; Committee Is Unanimous for 16-Year Limit, N.Y. TIMES, Jun. 22, 1937, at 1, but the proposal never reached the floor because by then abolishing child labor by statute was the preferred solution. See infra text accompanying notes $142-145$. 
to charges of hypocrisy given his prior support for the CLA. ${ }^{138}$ Second, the Twenty-First Amendment precedent, which was based on the unique problems posed by "dry" state legislatures and their malapportionment, now assumed greater importance. ${ }^{139}$ A plausible counterfactual exists in which the principal result that emerged from the Court fight (assuming that the switch-intime did not happen) was that all future amendments should be ratified by state conventions and that this was the preferred method for transforming the law. ${ }^{140}$

Most important, the Vandenberg Amendment confirmed that the constitutional culture that framed Congress's deliberations on the original CLA was gone. In 1924, state conventions were viewed as the way to slow down the Article Five bandwagon. ${ }^{141}$ Now they were seen as the only way to expedite ratification and salvage. The perspective on state legislatures, of course, flipped around the other way. Part of this was attributable to the CLA's difficulties, but prior to 1937 most lawyers did not attach any significance to them. FDR succeeded in changing that through his campaign for Court-packing, and the Vandenberg Amendment consolidated that shift by accepting his assertion that the CLA was representative rather than exceptional. Constitutional law would never be the same.

\section{THE SWITCH-IN-TIME AND COLEMAN V. MILLER}

Two days after Senator Vandenberg opened his counterattack against the President's position on the CLA, Justice Roberts changed his position on the New Deal in West

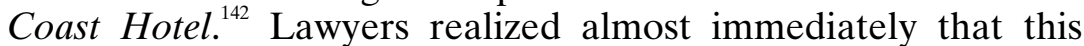
meant that a statute banning child labor could now be sustained. ${ }^{143}$ Just a week after the switch, The New York Times

138. Granted, the textual differences between the Vandenberg Amendment and the original CLA might have provided the President with the excuse he needed to conduct his own switch-in-time if necessary.

139. See supra text accompanying notes 88-94.

140. This was not the only moment when the New Deal could have been thrown in a radically different direction. See Gerard N. Magliocca, Huey P. Long and the Guarantee Clause, 83 TULANE L. REV. 1 (2008) (explaining how Senator Long's assassination in 1935 aborted an effort to use the Guarantee Clause to articulate the principles of the emerging constitutional regime).

141. See supra text accompanying notes $47-56$.

142. See West Coast Hotel Co. v. Parrish, 300 U.S. 379, 399-400 (1937) (upholding the Washington minimum wage statute and overruling Adkins v. Children's Hospital).

143. In the days immediately preceding West Coast Hotel, there were some suggestions that a law challenging Hammer $v$. Dagenhart should be enacted as an alternative to the CLA. See End Child Labor, supra note 128, at 20 ("Even while the new 
noted that "[e]vents of the last few days stimulated activity at both ends of Pennsylvania Avenue as well as in administrative circles generally on the problems of minimum wages and child labor." "144 Within a month, the bill that became the Fair Labor Standards Act was being drafted and interest in the CLA vanished as child labor was abolished by statute. ${ }^{145}$

The Court finally got involved in the CLA debate in 1939, but the opinions in Coleman obscured the significance of the ratification debate. ${ }^{146}$ Chief Justice Hughes' majority opinion held, among other things, that only Congress could place a time limit on the ratification of a constitutional amendment and that there was no indication that such a limit was contemplated for the CLA. ${ }^{147}$ But the Justices said nothing about the difficulty of getting an amendment ratified by the States and treated the amendment process as if it were unaffected by the Courtpacking fight. Indeed, Justice Robert H. Jackson later said that Coleman was important because if it had come out the other way "the precedent thus created would have placed serious restrictions upon the amending process for all time to come." The elected branches, however, established the real restrictions on Article Five in 1937 by persuading the country that state

amendment is pending, they may find it possible, in the words of the President, to take action-now! This is the purpose of the bill just introduced by Senator WHEELER which ... would make the products of child labor subject to the laws of the State into which they are shipped."); $i d$. ("What opponents of child labor need to keep principally in mind is that they are not necessarily confronted by an 'either-or' course.").

144. Stark, supra note 134 , at 70.

145. See The President's Position, N.Y. TIMES, May 16, 1937, at 66 (“[R]ecent decisions of the Supreme Court offer reasonable hope that the problem of child labor can be dealt with satisfactorily without either an amendment of the Constitution or a forced change in the membership of the court itself."); see also The Wheeler-Johnson Bill, N.Y. TIMES, May 6, 1937, at 24 ("A child labor amendment is itself still desirable. But it does not seem wise to reject three-quarters of a loaf now on the ground that it may injure one's chances of getting a whole loaf perhaps several years hence."). No states ratified the CLA after the switch-in-time.

146. Coleman v. Miller, 307 U.S. 433, passim (1939). The Court did mention that the President issued a letter in support of the CLA, but that was the only comment on the events described in the text. See id. at $451 \mathrm{n} .28$.

147. See id. at 451-54. The constitutionality of the FLSA was unclear at this point, thus a ruling that the CLA was no longer valid would have looked ominous. See ACKERMAN, supra note 3, at 262 ("Congress had acted as if it were confident that the Court would no longer defend cases like Hammer and would allow statutory action without the need for further constitutional amendment. But if the Court had upheld the Kansans' complaint, it would be placing this assumption, and hence the Fair Labor Standards Act, under a cloud.").

148. JACKSON, supra note 59, at 261. 
legislatures were the place where constitutional amendments go to die. ${ }^{149}$

\section{CONCLUSION}

Textual changes to the Constitution did not end with the defeat of the Child Labor Amendment. ${ }^{150}$ What did end was the premise that getting these proposals ratified by state legislatures would be easy. ${ }^{151}$ The President's plan to make the CLA into the poster child for the amendment process was successful even though its object-supporting Court-packing-was not. The failure of the ERA in the 1970s reinforced this notion and turned the futility of state ratification into a truism, to the point that today nobody is seriously pursuing constitutional change through Article Five.

By showing that the current construction of Article Five is just that - a construction rather than a fact-this Article seeks to provoke a new discussion about the merits of using the constitutional amendment process. While there are circumstances where agreeing on a textual formula for legal change or moving that language through Congress may not be the best course of action, the assumption that federalism is an insurmountable obstacle to reform should be reexamined.

149. Justice Jackson also accepted this argument. See id. ("The difficulty of amending the Constitution to make sure that it says what it already was intended to say was illustrated by the fate of the proposed amendment.").

150. The Twenty-Second Amendment took four years to ratify, which was the longest period for any successful proposal at that time. See KYVIG, supra note 7, at 32731 (discussing the amendment's passage by Congress); see also AMAR, supra note 21 , at 433 (stating that ratification occurred in 1951); supra text accompanying note 24 (stating that the Sixteenth Amendment took almost as long to ratify). By contrast, the four amendments ratified in the 1960s and 1970s were rapidly adopted by the States. See KYVIG, supra note 7, at 355-56 (stating that the Twenty-Third Amendment was ratified in less than ten months); see also AMAR, supra note 21, at 442 (stating that the TwentyFourth Amendment was ratified in two years); id. at 445 (stating that the Twenty-Sixth Amendment was ratified in just four months); $i d$. at 449 (stating that the Twenty-Fifth Amendment was ratified in less than two years).

151. The proposed constitutional amendment to permit Congress to ban flag burning might constitute an exception, in the sense that one could say that the states would ratify such a proposal in no time flat if they were given the chance. There is no way to know, though, unless that amendment receives the necessary support in the Senate and in the House of Representatives. 